ISSN $0258-7122$

Bangladesh J. Agril. Res. 32(3) : 369-374, September 2007

\title{
INFLUENCE OF N AND P FERTILIZER APPLICATION ON ROOT GROWTH, LEAF PHOTOSYNTHESIS AND YIELD PERFORMANCE OF GROUNDNUT
}

\author{
M. Altab Hossain ${ }^{1}$ And A. Hamid 2
}

\begin{abstract}
Field experiments were carried out at the Bangabandhu Sheikh Mujibur Rahman Agricultural University, Gazipur during 2000-2002 to evaluate the effect of N and $\mathrm{P}$ applicaiton on the root growth, leaf photosynthesis and yield of groundnut (var. Basantibadam). Four levels of N (0, 20, 40 and $60 \mathrm{~kg} \mathrm{~N} / \mathrm{ha}$ ) and four levels of $\mathrm{P}(0,13,26$ and $39 \mathrm{~kg} \mathrm{P} / \mathrm{ha})$ were the treatment variables. The trial was set up in a randomized complete block design under factorial arrangement with three replications. Application of $\mathrm{N}$ and $\mathrm{P}$ fertilizer exerted significant effects on root development, photosynthesis, yield contributing characters and pod yield of the crop. Plant receiving $60 \mathrm{~kg} \mathrm{~N}$ and $39 \mathrm{~kg}$ P/ha had larger root system, greater photosynthetic rate and better yield contributing characters that resulted in the maximum pod yield which, however, was not significantly different from $\mathrm{N}_{60} \mathrm{P}_{26}$ treatment. Hence, it is recommended that higher yield of Basantibadam can be obtained from $\mathrm{N}_{60} \mathrm{P}_{26} \mathrm{~kg} / \mathrm{ha}$ in salna silty clay loam soil of Madhupur tract (AEZ 28) of Bangladesh.
\end{abstract}

Key Words: $\mathrm{N}$ and $\mathrm{P}$ application, root growth, leaf photosynthesis, groundnut.

\section{Introduction}

Groundnut (Arachis hypogaea L.) is an important food legume of Bangladesh which was grown on 26720 hectares in 2005 producing 34,240 metric tons (BBS, 2005), the average pod yield being $1300 \mathrm{~kg} / \mathrm{ha}$ which is very low as compared to world's average yield of $2200 \mathrm{~kg} / \mathrm{ha}$. A major cause of this low yield in the use of low yielding varieties with little or no use of fertilizers.

Growth and development of crops depend largely on the development of root system. Nitrogen is the key plant nutrient that stimulates root and shoot growth. Jana et al. (1990) also reported that $40 \mathrm{~kg} \mathrm{~N} / \mathrm{ha}$ produced a pod yield of $1.48 \mathrm{t} / \mathrm{ha}$ compared to $0.90 \mathrm{t} / \mathrm{ha}$ with no nitrogen. Effect of phosphorus on root development is well established. In groundnut cultivation, farmers apply very little amount or no phosphorus fertilizer. Sharma and Yadav (1997) reported that

${ }^{1}$ Principal Scientific Officer, OFRD, Shyampur, Rajshahi, ${ }^{2}$ Professor, Deptt. of Agronomy, BSMRAU, Salna, Gazipur, Bangladesh. 
phosphorus plays a beneficial rotle in legume growth and promoting extensive root development and thereby ensuring a good yield. Addition of $\mathrm{N}$ and $\mathrm{P}$ fertilizer enhanced root development which improves the supply of other nutrients and water to the growing parts of the plants, resulting in an increased photosynthetic area and thereby more dry matter accumulation (Prihar and Tripathi, 1989). The study attempts to assess the effect of $\mathrm{N}$ and $\mathrm{P}$ fertilization on the ramification of the root system, leaf photosynthesis and the yield of groundnut.

\section{Materials and Method}

A field experiment was conducted at the farm of the Bangabandhu Sheikh Mujibur Rahman Agricultural University (BSMRAU), Salna, Gazipur during 2000-2002. The texture of the experimental soil was sity clay loam belonging to Salna series under AEZ-28. The soil is slightly acidic in reaction (pH 6.1) with $1.7 \%$ organic matter, $0.06 \%$ total $\mathrm{N}, 8.04 \mathrm{ppm}$ available $\mathrm{P}, 0.19 \mathrm{c} \mathrm{mol} \mathrm{\textrm {kg } ^ { - 1 }}$ exchangeable K and $7.02 \mathrm{ppm}$ available S. Bulk density was low in the upper 0$10 \mathrm{~cm}$ depth $\left(1.3 \mathrm{~g} \mathrm{~cm}^{-3}\right)$ and it tended to increase $\left(1.4\right.$ to $\left.1.5 \mathrm{~g} \mathrm{~cm}^{-3}\right)$ with increasing depth (10-20 to $30-40 \mathrm{~cm})$.

Four levels of nitrogen $(0,20,40$, and $60 \mathrm{~kg} \mathrm{~N} / \mathrm{ha})$ and four levels of phosphorus $(0,13,26$, and $39 \mathrm{~kg} \mathrm{P} / \mathrm{ha})$ fertilizers constituted the experimental variable. The experiment was laid out in a randomized complete block design (RCBD) under factorial arrangement with three replications. The unit plot size was $4.5 \mathrm{~m} \times 3.2 \mathrm{~m}$. Fertilizer at the rate of $42 \mathrm{~kg} \mathrm{~K}_{2} \mathrm{O}$ and $30 \mathrm{~kg} \mathrm{~S} /$ ha were applied in the form of muriate of potash and gypsum, respectively. Nitrogen from urea and $\mathrm{P}$ from triple superphosphate were applied to the field as per treatment. Seeds of groundnut (var. Basantibadam) were sown at $15 \mathrm{~cm}$ spacing in $40 \mathrm{~cm}$ apart rows on 04 February in 2000 and 31 January in 2001. Irrigation was done as and when required. Malathion was sprayed two times at 40 and 70 days after emergence (DAE) to control caterpillar. Bavisteen at the rate of $2 \mathrm{~g} /$ litre of water was sprayed three times at an interval of 25 days starting from 30 DAE as a preventive measure of Tikka (Cercospora personata) disease.

Root samples were collected at 30,60, and 90 DAE for determining root length by using a root scanner (Delta-T Devices Ltd. Model NV-M-12). Then, the roots were oven dried at $70^{\circ} \mathrm{C}$ to a constant weight and the final weight was recorded. Root length density (RLD) and root mass density (RMD) were determined using the following formulae: $\mathrm{RLD}=\mathrm{R}_{1} / \mathrm{S}_{\mathrm{v}} \mathrm{cm} \mathrm{cm}^{-3}$ and $\mathrm{RMD}=\mathrm{W}_{\mathrm{r}}$ 
/ $\mathrm{S}_{\mathrm{v}} \mathrm{g} \mathrm{cm}^{-3}$ where, $\mathrm{R}_{1}=$ total length $(\mathrm{cm})$ of the sample, $\mathrm{Sv}=$ volume of the sampler $\left(\mathrm{cm}^{-3}\right)=\pi \mathrm{r}^{2} \mathrm{~h}, \mathrm{r}=$ radius of the sampler, $\mathrm{h}=$ height of the sampler and $\mathrm{W}_{1}$ $=$ total root weight. Leaf photosynthesis was measured at 30 and 60 DAE of groundnut with portable photosynthesis measuring device (LICOR 6200, Lincoln, Nebraska). Photosynthetic rates were measured on the fully expanded young leaf on a clear sunny day between 11:00 to 13:00 hours.

At maturity (146 DAE), an area of $8 \mathrm{~m}^{2}$ was harvested from centre of each plot avoiding the border plants. The pod weight/plot was recorded at $12 \%$ moisture. Yield contributing characters were also recorded. Data were subjected to analysis of variance (ANOVA) and Least Significant Difference (LSD) test was used for mean separation.

\section{Results and Discussion}

All the parameters viz., root length density, root mass density, leaf photosynthesis, yield attributes, and yield of groundnut showed similar results in both the years, hence the pooled data are shown and discussed.

Root length density and root mass density: The root length density (RLD) and root mass density (RMD) varied significantly due to different levels of $\mathrm{N}$ and $\mathrm{P}$ application (Table 1 and 2). RLD in early stage (30 DAE) was similar over the treatments and thereafter the growth was rapid (Table 1). RLD showed positive response to added $\mathrm{N}$ and $\mathrm{P}$ upto $\mathrm{N}_{60} \mathrm{P}_{39} \mathrm{~kg} / \mathrm{ha}$ at every stage, however, the difference between $\mathrm{N}_{60} \mathrm{P}_{39}$ and $\mathrm{N}_{60} \mathrm{P}_{26} \mathrm{~kg}$ /ha was not statistically significant. The control $\left(\mathrm{N}_{0} \mathrm{P}_{0}\right)$ gave the lowest RLD irrespective of growth stages. A similar trend was observed for root mass density (Table 2). In general, RMD increased with plant age, reaching the maximum at 90 DAE regardless of treatments. As evident from Table 1 and 2, root growth decreased drastically when the plants suffered from $\mathrm{P}$ deficiency.

Table 1. Root length density $\left(\mathrm{cm} \mathrm{cm}^{-3}\right)$ of groundnut at different growth periods as influenced by $\mathbf{N}$ and $\mathbf{P}$ application (average of 2 years).

\begin{tabular}{|c|c|c|c|c|c|c|c|c|c|c|c|c|}
\hline \multirow{3}{*}{$\begin{array}{l}\text { N levels } \\
\text { (kg/ha) }\end{array}$} & \multicolumn{12}{|c|}{ P level (kg/ha) } \\
\hline & \multicolumn{4}{|c|}{ At 30 DAE } & \multicolumn{4}{|c|}{ At 60 DAE } & \multicolumn{4}{|c|}{ At 90 DAE } \\
\hline & 0 & 13 & 26 & 39 & 0 & 13 & 26 & 39 & 0 & 13 & 26 & 39 \\
\hline 0 & 0.10 & 0.12 & 0.14 & 0.15 & 0.18 & 0.19 & 0.21 & 0.24 & 0.20 & 0.23 & 0.26 & 0.28 \\
\hline 20 & 0.11 & 0.14 & 0.16 & 0.16 & 0.20 & 0.27 & 0.29 & 0.29 & 0.21 & 0.32 & 0.36 & 0.36 \\
\hline 40 & 0.12 & 0.16 & 0.19 & 0.20 & 0.21 & 0.28 & 0.35 & 0.36 & 0.24 & 0.35 & 0.38 & 0.39 \\
\hline 60 & 0.13 & 0.17 & 0.22 & 0.23 & 0.22 & 0.28 & 0.35 & 0.37 & 0.26 & 0.37 & 0.39 & 0.41 \\
\hline $\begin{array}{c}\mathrm{LSD}_{(0.05)} \\
(\mathrm{N} \times \mathrm{P})\end{array}$ & \multicolumn{4}{|c|}{0.02} & \multicolumn{4}{|c|}{0.01} & \multicolumn{4}{|c|}{0.02} \\
\hline
\end{tabular}


Table 2. Root length density $\left(\mathrm{mg} \mathrm{cm}^{-3}\right)$ of groundnut at different growth periods as affected by $\mathbf{N}$ and $\mathbf{P}$ application (average of 2 years).

\begin{tabular}{|c|c|c|c|c|c|c|c|c|c|c|c|c|}
\hline \multirow{3}{*}{$\begin{array}{l}\text { N levels } \\
\text { (kg/ha) }\end{array}$} & \multicolumn{12}{|c|}{ P level (kg/ha) } \\
\hline & \multicolumn{4}{|c|}{ At $30 \mathrm{DAE}$} & \multicolumn{4}{|c|}{ At $60 \mathrm{DAE}$} & \multicolumn{4}{|c|}{ At $90 \mathrm{DAE}$} \\
\hline & 0 & 13 & 26 & 39 & 0 & 13 & 26 & 39 & 0 & 13 & 26 & 39 \\
\hline 0 & 0.10 & 0.16 & 0.18 & 0.18 & 0.15 & 0.23 & 0.26 & 0.27 & 0.18 & 0.32 & 0.33 & 0.33 \\
\hline 20 & 0.13 & 0.18 & 0.19 & 0.19 & 0.20 & 0.27 & 0.28 & 0.29 & 0.21 & 0.39 & 0.43 & 0.43 \\
\hline 40 & 0.15 & 0.19 & 0.20 & 0.20 & 0.22 & 0.29 & 0.30 & 0.30 & 0.30 & 0.47 & 0.50 & 0.51 \\
\hline 60 & 0.16 & 0.19 & 0.21 & 0.22 & 0.23 & 0.29 & 0.32 & 0.33 & 0.31 & 0.35 & 0.61 & 0.63 \\
\hline $\begin{array}{l}\operatorname{LSD}_{(0.05)} \\
(\mathrm{N} \times \mathrm{P})\end{array}$ & \multicolumn{4}{|c|}{0.02} & \multicolumn{4}{|c|}{0.03} & \multicolumn{4}{|c|}{0.06} \\
\hline
\end{tabular}

Leaf photosynthesis: Table 3 shows leaf photosynthetic $(\mathrm{Pn})$ rate of groundnut as influenced by $\mathrm{N}$ and $\mathrm{P}$ fertilizer at two growth stages. Regardless of fertilizer treatments, Pn rates decreased with the plant age. The maximum Pn rate was observed at 30 DAE. Similar trend was reported by Hiremath et al. (1994) in groundnut and Akteruzzaman (1998) in mungbean. The decline in Pn rate of groundnut with age may be due to mutual shading and increased ratio of older to younger leaves, in addition to increased rates of dark respiration and translocation of assimilates. Fertilizer treated ( $\mathrm{N}$ and $\mathrm{P}$ ) plants gave significantly high Pn value over the control. The Pn rate increased with increasing levels of $\mathrm{N}$ and $\mathrm{P}$ combination, indicating a requirement of both $\mathrm{N}$ and $\mathrm{P}$ fertilizer for higher photosynthesis rate. The increased supply of both $\mathrm{N}$ and $\mathrm{P}\left(\mathrm{N}_{60} \mathrm{P}_{39}\right)$ resulted in the highest Pn which was statistically identical with $\mathrm{N}_{60} \mathrm{P}_{26}$.

Table 3. Leaf photosynthesis $\left(\mu \mathrm{mol} \mathrm{m}-^{-2} s^{-1}\right)$ of groundnut at different growth periods as Influenced by $N$ and $P$ application (average of 2 years)

\begin{tabular}{|c|c|c|c|c|c|c|c|c|}
\hline \multirow{2}{*}{$\begin{array}{l}\mathrm{N} \text { levels } \\
\text { (kg/ha) }\end{array}$} & \multicolumn{8}{|c|}{ P level (kg/ha) } \\
\hline & \multicolumn{4}{|c|}{ At 30 DAE } & \multicolumn{4}{|c|}{ At 60 DAE } \\
\hline & 0 & 13 & 26 & 39 & 0 & 13 & 26 & 39 \\
\hline 0 & 18.70 & 19.47 & 20.10 & 20.30 & 13.55 & 14.00 & 14.60 & 15.00 \\
\hline 20 & 21.60 & 24.89 & 25.21 & 25.40 & 17.20 & 20.79 & 21.11 & 21.36 \\
\hline 40 & 23.39 & 26.50 & 27.47 & 27.51 & 19.28 & 22.48 & 23.38 & 23.61 \\
\hline 60 & 23.90 & 26.66 & 29.09 & 29.40 & 19.64 & 22.17 & 25.60 & 25.80 \\
\hline $\begin{array}{c}\mathrm{LSD}_{(0.05)} \\
(\mathrm{N} \times \mathrm{P})\end{array}$ & \multicolumn{4}{|c|}{1.75} & \multicolumn{4}{|c|}{1.99} \\
\hline
\end{tabular}

Yield and yield contributing characters: Both nitrogen and phosphorus application rates exerted significant influence on the number of mature pods/ plant, 100-seed weight and pod yield of the crop (Table 4). The number of mature pods per plant increased from 15 to 24 with increasing rates of $\mathrm{N}$ and $\mathrm{P}$ 
application, reaching the maximum value at $\mathrm{N}_{60} \mathrm{P}_{39}$ treatment. However, the difference between $\mathrm{N}_{60} \mathrm{P}_{26}$ and $\mathrm{N}_{60} \mathrm{P}_{39}$ treatments was not statistically significant. It was observed that the response to $\mathrm{P}$ was relatively high in the absence of nitrogen. Variation in 100-seed weight was also observed for the different $\mathrm{N}$ and P levels and varied from 39.55 to $56.22 \mathrm{~g}$; the lowest being recorded for control plot. Interaction between $\mathrm{N}$ and $\mathrm{P}$ fertilizer levels on 100-seed weight followed the same trend as was observed in the number of mature pods/plant (Table 4). The pod yield varied from 1166 to $2820 \mathrm{~kg} / \mathrm{ha}$ depending upon the doses of $\mathrm{N}$ and P. Increased rate of $\mathrm{N}$ and $\mathrm{P}$ fertilizer application upto $\mathrm{N}_{60} \mathrm{P}_{39}$ increased pod yield and it was statistically identical with $\mathrm{N}_{60} \mathrm{P}_{26} \mathrm{~kg} / \mathrm{ha}$. The soil was poor in total $\mathrm{N}$ and available $\mathrm{P}$. As a result, the response was higher when $60 \mathrm{~kg} \mathrm{~N}$ and $39 \mathrm{~kg}$ $\mathrm{P} /$ ha was added. The yield advantage from $\mathrm{N}_{60} \mathrm{P}_{26}$ and $\mathrm{N}_{60} \mathrm{P}_{39} \mathrm{~kg} /$ ha fertilizer application was due to higher root growth. The results are in conformity with the observation of Bhatol et al. (1994) in groundnut. Plants grown under no application of $\mathrm{N}$ and $\mathrm{P}$ fertilizer $\left(\mathrm{N}_{\mathrm{o}} \mathrm{P}_{\mathrm{o}}\right)$ gave the lowest pod yield.

Table 4. Influence of $N$ and $P$ application on the number of pods/plant, 100-seed weight and pod yield of groundnut (average of 2 years).

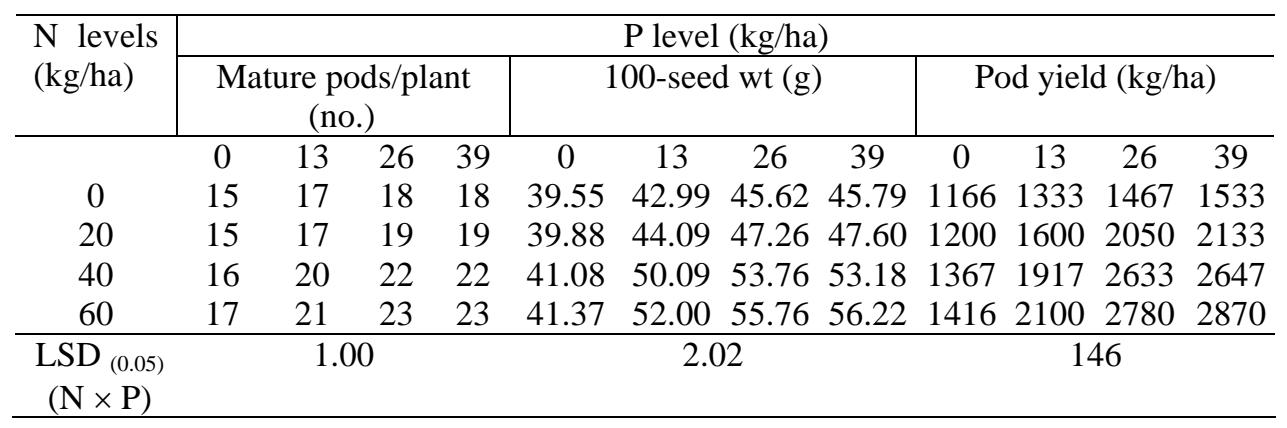

Results revealed that $\mathrm{N}$ and $\mathrm{P}$ deficiency in groundnut resulted in poor root development and ultimately reduced yield. Therefore, application of $\mathrm{N}$ and $\mathrm{P}$ fertilizer offers a large scope for obtaining higher yield of groundnut. It appears that good yield of Basantibadam can be harvested at $\mathrm{N}_{60} \mathrm{P}_{26} \mathrm{~kg} / \mathrm{ha}$ in silty clay loam soil of Salna area (AEZ 28) of Bangladesh.

\section{References}

Aktaruzzaman M.A. 1998. Influence of nitrogen and phosphorus fertilizer on the productivity of mungbean (Vigna radiata L.). Ph.D. Disst. Res., Agron. Divn., Institute of Post Graduate Studies in Agriculture, Salna, Gazipur, p 24. 
Bangladesh Bureau of Statistics (BBS). 2005. Statistical Year Book of Bangladesh. Bangladesh Bureau of Statistics, Statistics Division, Ministry of Planning, Govt. of the People's Republic of Bangladesh. p. 150.

Bhatal, D.P., N.A. Patel and R.P. Pavaya. 1994. Effect of nitrogen, phosphorus and zinc application on yield and uptake of nutrients by groundnut. Indian J. Agric. Res. 28:209-213.

Hriemath, S.M., K.V. Janardhan, A. F. Habib and Y.C. Panchal. 1984. Varietal differences in leaf photosynthetic rate and its relationship with certain leaf characters and yield in groundnut (Arachis hypogaea L.). J. Nuclear Agric. Bio. 13:103-105.

Jana, P.K., S. Ghatak, A. Barik and B.C. Biswas. 1990. Response of summer groundnut to nitrogen and potassium. Indian. J. Agron. 35:137-143.

Prihar, S.S. and R.S. Tripathi. 1989. Dry matter, nodulation and nutrient uptake in chickpea as influenced by irrigation and phosphorus. Expt. Agric. 25:349-355.

Sharma, B.M. and J.S.P. Yadav. 1997. Availability of phosphorus to grain as influenced by phosphatic fertilization and irrigation regimes. Indian J. Agric. Sci. 46:205-210. 